University of Nebraska - Lincoln

DigitalCommons@University of Nebraska - Lincoln

Perspectives on the Diagnosis, Epizootiology, and Control of the 1973 Duck Plague Epizootic in Wild Waterfowl at Lake Andes, South Dakota

\author{
Gary Pearson \\ USGS Northern Prairie Wildlife Research Center \\ Delmar Cassidy \\ Veterinary Services Diagnostic Laboratory, U.S. Department of Agriculture, Animal and Plant Health \\ Inspection Service, Veterinary Services
}

Follow this and additional works at: https://digitalcommons.unl.edu/usgsnpwrc

Part of the Other International and Area Studies Commons

\footnotetext{
Pearson, Gary and Cassidy, Delmar, "Perspectives on the Diagnosis, Epizootiology, and Control of the 1973 Duck Plague Epizootic in Wild Waterfowl at Lake Andes, South Dakota" (1997). USGS Northern Prairie Wildlife Research Center. 111.

https://digitalcommons.unl.edu/usgsnpwrc/111
}

This Article is brought to you for free and open access by the US Geological Survey at DigitalCommons@University of Nebraska - Lincoln. It has been accepted for inclusion in USGS Northern Prairie Wildlife Research Center by an authorized administrator of DigitalCommons@University of Nebraska - Lincoln. 


\title{
PERSPECTIVES ON THE DIAGNOSIS, EPIZOOTIOLOGY, AND CONTROL OF THE 1973 DUCK PLAGUE EPIZOOTIC IN WILD WATERFOWL AT LAKE ANDES, SOUTH DAKOTA
}

\author{
Gary L. Pearson ${ }^{1.3}$ and Delmar R. Cassidy ${ }^{2.4}$ \\ ' Northern Prairie Wildlife Research Center, U.S. Department of the Interior, Fish and Wildlife Service, Bureau of \\ Sport Fisheries and Wildlife (now U.S. Geological Survey, Biological Resources Division), 8711 37th Street, S.E., \\ Jamestown, North Dakota 58401, USA \\ ${ }^{2}$ Veterinary Services Diagnostic Laboratory (now National Veterinary Services Laboratories), U.S. Department of \\ Agriculture, Animal and Plant Health Inspection Service, Veterinary Services, P.O. Box 844, Ames, lowa 50010, USA \\ ${ }_{3}$ Present address: Prairie Veterinary Hospital, 1305 Business Loop East, Jamestown, North Dakota 58401, USA \\ 4 Present address: 1005 West 16th Street, Ames, lowa 50010, USA
}

ABSTRACT: An epizootic of duck plague occurred in early 1973 in a population of 163,500 wild waterfowl, primarily mallards (Anas platyrhynchos), wintering on Lake Andes and the nearby Missouri River in southeastern South Dakota (USA). The diagnosis was based on pathologic lesions and confirmed by virus isolation. Control measures included quarantine, attempts to reduce virus contamination of the area, dispersal of waterfowl, and monitoring of wild waterfowl populations for mortality. The epizootic resulted in documented mortality of $18 \%$ and estimated mortality of $26 \%$ of the waterfowl at risk. Prompt implementation of control measures might have limited mortality to approximately $8 \%$. Losses during the epizootic were equivalent to $0.12 \%$ of the annual mortality in the North American 1996 fall population of $80,000,000$ wild ducks. The most likely sources of the infection were free-flying wild mallard or American black duck (Anas rubripes) carriers from the upper midwestern or northeastern United States. Duck plague serum neutralization antibodies were demonstrated in $31 \%$ of 395 apparently healthy mallards sampled prior to dispersal of the flock at Lake Andes, suggesting that tens of thousands of potential duck plague carriers entered the wild waterfowl populations of all four major flyways. Consequently, the absence of major epizootics of duck plague in wild waterfowl in the subsequent two decades is evidence that substantial numbers of duck plague carriers can occur in wild waterfowl populations without resulting in epizootic mortalities. The failure to isolate duck plague virus from apparently healthy mallards sampled during the epizootic raises questions concerning the validity of conclusions regarding the status of duck plague in wild waterfowl based upon negative results of random surveys conducted in the absence of epizootics.

Key words: Control, diagnosis, disease, duck plague, duck virus enteritis, epizootiology, wild waterfowl.

\section{INTRODUCTION}

Duck plague (duck virus enteritis, DVE), initially thought to be a form of fowl plague, was first reported in the Netherlands (Baudet, 1923). Epizootics continued to occur in the Netherlands (Jansen, 1968) and the disease has appeared in Belgium (Devos et al., 1964), China (Jansen and Kunst, 1964), India (Mukerji et al., 1963, 1965), Britain (Hall and Simmons, 1972; Gough and Alexander, 1990), France (Lucam, 1949), and Thailand (Leibovitz, 1991). Duck plague, an acute, contagious herpesvirus infection of ducks, geese and swans, was first recognized on North America in commercial white Pekin ducks (Anas platyrhynchos) on Long Island, New York (USA), in January 1967 (Leibovitz and Hwang, 1968) and subsequently was diagnosed in captive and feral ornamental and free-flying wild waterfowl in the northeastern United States (Leibovitz, 1968; Locke et al., 1968).

A duck plague epizootic in free-flying wild waterfowl on Flanders Bay (Long Island, New York, USA) in November and December 1967 resulted in an observed mortality of 89 American black ducks (Anas rubripes) and 19 mallards (Anas platyrhynchos) among the estimated 1,500 black ducks and 375 mallards on the bay, as well as one Canada goose (Branta canadensis) and one bufflehead (Bucephala albeola) (Leibovitz, 1968). An epizootic on 
the Finger Lakes (New York, USA) in early 1994 resulted in an estimated mortality of 1,200 wild black ducks, mallards, and Canada geese (Friend and Cross, 1995). The only other major epizootic of duck plague recognized in free-flying wild waterfowl occurred from January to early March 1973 at Lake Andes (South Dakota, USA), and resulted in the largest mortality recorded for the disease in wild waterfowl.

\section{WILD WATERFOWL HISTORY OF THE LAKE ANDES AREA}

Lake Andes is a 1,983 ha natural lake in southeastern South Dakota $\left(43^{\circ} 9^{\prime} \mathrm{N}\right.$, $98^{\circ} 24^{\prime} \mathrm{W}$ ) approximately $18 \mathrm{~km}$ from the Nebraska (USA) border and $11 \mathrm{~km}$ north and east of the Missouri River. Traditionally, waterfowl wintered on the Missouri River in the Lake Andes area and, with the development of artesian wells on Lake Andes (the first was drilled in 1898), waterfowl began exchanging between the river and the lake during the winter in the early 1900's, according to Lake Andes National Wildlife Refuge files (LANWRF; Lake Andes, South Dakota, USA).

The Lake Andes National Wildlife Refuge was established on Owens Bay of Lake Andes in 1936. That same year, a dike was constructed between Owens Bay and the main body of the lake and a new 3,409 I per minute $(1 / \mathrm{m})$ well was drilled to permit better water management on the bay and other wetlands on the refuge. The refuge includes 264 ha of uplands and 116 ha of water and marsh on Owens Bay held in fee title by the U.S. Government (U.S. Department of the Interior, Washington, D.C., USA), and is managed by the U.S. Fish and Wildlife Service (USFWS) (in 1973, the USFWS Bureau of Sport Fisheries and Wildlife [BSFW]). In addition, the main body of Lake Andes is under easement to the USFWS as a refuge from the State of South Dakota. In 1957, the original well on the Owens Bay unit was replaced with a new 286.5 m-deep well capable of delivering $2,652 \mathrm{l} / \mathrm{m}$ of water with a temperature of $18.3 \mathrm{C}$. The refuge pro- vided waterfowl production, migration and wintering habitat. Approximately 142 ha on the Owens Bay unit were usually planted to corn (Zea mays) and sorghum (Sorghum vulgare) to reduce crop depredations by waterfowl on surrounding private farmlands and provide winter food for deer and upland gamebirds. Artificial feeding of waterfowl was conducted once on the refuge, during the severe winter of 1968-1969 (LANWRF).

In 1953, Fort Randall Dam was completed on the Missouri River $11 \mathrm{~km}$ from Lake Andes, and the reservoir (Lake Francis Case) and $10.5 \mathrm{~km}$ of the river below the dam were closed to waterfowl hunting. During the winter, releases from the dam for hydropower generation vary from 0 to $3,253 \mathrm{~m}^{3}$ per second $\left(\mathrm{m}^{3} / \mathrm{sec}\right)$ and average $1,859 \mathrm{~m}^{3} / \mathrm{sec}$, and provide 1.6 to $8.0 \mathrm{~km}$ of open water on the river below the dam. Wintering waterfowl moved between the refuge and the open water on the river, with the numbers on each area varying with weather conditions and water releases from the dam (LANWRF).

The refuge historically produced 400 to 1,500 ducks per year, $60 \%$ of which were blue-winged teal (Anas discors). Peak populations on the refuge during fall migrations reached 250,000 ducks and 1,000 to 5,000 Canada geese. From 1942 through 1972, wintering ducks on the refuge, which were $99 \%$ mallards, ranged from 20,000 in 1956 to 200,000 in $1967(\bar{x}=$ $77,000)$. Wintering Canada geese on the refuge during this period ranged from 250 in 1967 to 20,000 in 1950 and 1951 ( $\bar{x}=$ 6,100 ). Prior to 1973 , mallards banded at Lake Andes were recovered in 26 states in all four major waterfowl flyways and from four Canadian provinces (LANWRF). Annual winter mortality on the refuge was 500 to 1,000 waterfowl, with lead poisoning and gunshot injuries being the principal causes of death (LANWRF).

\section{Diagnosis}

THE 1973 DUCK PLAGUE EPIZOOTIC

On 13 January 1973 refuge personnel first noticed mortality of waterfowl in ap- 
parently good body condition, in addition to the usual emaciated hunting cripples and lead poisoning victims. On 15 January 1973, 500 dead mallards and 20 dead Canada geese were collected on the refuge. Refuge personnel contacted the BSFW's Northern Prairie Wildlife Research Center (NPWRC; Jamestown, North Dakota, USA) on Friday 19 January 1973 to request diagnostic assistance. Lake Andes is approximately $425 \mathrm{~km}$ from Jamestown; so, in order to expedite diagnosis, refuge personnel were advised to submit representative dead and affected live waterfowl to the South Dakota State University Veterinary Research and Diagnostic Laboratory (SDSUNRDL; Brookings, South Dakota, USA). Six dead and seven sick mallards from the refuge were submitted to the diagnostic laboratory later that day. On 22 January 1973 1,250 dead mallards, five dead Canada geese and one dead American wigeon (Anas americana) were collected on the refuge, bringing the losses to 3,044 ducks and 25 Canada geese.

On Tuesday 23 January 1973 the diagnostic laboratory reported to NPWRC that mouse protection tests on sera from the mallards were negative for botulism. A tentative diagnosis of duck plague was made based upon necropsy findings of hemorrhagic enteritis not necessarily limited to the intestinal lymphoid annular bands, ecchymotic hemorrhages in the area of Meckel's diverticulum, necrotic mucosal lesions in the esophagus and intestines, and histopathologic findings of focal necrosis and intranuclear inclusion bodies in the liver. At that time, duck plague was classified as an exotic disease by the U.S. Department of Agriculture, Animal and Plant Health Inspection Service (USDA/APHIS; Washington, D.C., USA), and following procedures established for duck plague in free-flying wild waterfowl, the USDA/APHIS Veterinary Services veterinarian in charge in South Dakota and the BSFW's Patuxent Wildlife Research Center (Laurel, Maryland, USA) were immediately notified of the tentative diagnosis.

On Thursday 25 January 1973 a veterinarian from NPWRC (G. L. Pearson) and personnel from SDSU/VRDL met with refuge personnel at Owens Bay to examine additional specimens. Dead mallards collected from the shore of Owens Bay were observed to be in good body condition and frequently to have bloody diarrhea and bloody fluid draining from their bills and nares. Dead mallards and Canada geese frequently were found with the bill pointed downward and perpendicular to the surface or the head and neck extended over the back, the legs and wings partially extended and the tail fanned. Prolapse of the penis was common in male mallards. Dead Canada geese had evidence of bloody diarrhea. Affected birds had increased thirst and drank frequently, appeared depressed, had reduced wariness and reluctance to $\mathrm{fly}$, and frequently sought dense vegetation. Moribund mallards frequently had violent clonic seizures characterized by swimming in tight circles with the head over the back and rapid beating of the wings.

On necropsy, mallards had extensive hemorrhages involving the heart, liver, esophageal-proventricular junction, and intestinal annular bands, and often the spleens were dark. Hemorrhages frequently were visible from the serosal surfaces of the proventriculus and of the intestines at the annular bands and Meckel's diverticulum. Copious bloody fluid frequently was found in the intestinal lumen. Hemorrhagic and necrotic mucosal lesions frequently were found paralleling the longitudinal folds in the esophagus and in the ceca, colon, and cloaca. Button-like ulcers were present at the intestinal lymphoid discs of Canada geese. Proctor et al. (1975) have described in detail the signs and gross and microscopic lesions observed in the freeflying wild waterfowl dying of duck plague in the epizootic at Lake Andes.

Based upon the histopathologic lesions observed in the mallards submitted to 
SDSU/NRDL on 19 January 1973 and the demonstration of the entire spectrum of gross lesions described as pathognomonic for duck plague (Leibovitz, 1971) in mallards and Canada geese examined at the refuge on 25 January 1973, a diagnosis of duck plague was made. On 26 January 1973 a press release was issued by the BSFW to the Associated Press and United Press offices in Pierre (South Dakota, USA) reporting the occurrence of the epizootic in waterfowl at the Lake Andes National Wildlife Refuge, and the Canadian Wildlife Service (Hull, Quebec, Canada) and the chairmen of the Central and Mississippi flyway councils were advised of the situation.

In a reconnaissance of the Missouri River below Fort Randall Dam by boat on 26 January $1973,30,000$ to 40,000 mallards and small numbers of Canada geese, common goldeneyes (Bucephala clangula) and common mergansers (Mergus merganser) were observed on the river. Six dead and six moribund mallards were collected and 40 to 50 additional mallards with reduced wariness and impaired flight were observed. The mallards that were collected had the same signs and gross lesions that had been observed in the mallards at the refuge.

Tissues from mallards and Canada geese collected at the refuge by SDSUNRDL personnel were submitted to the USDA APHIS Veterinary Services Diagnostic Laboratory (VSDL; Ames, Iowa, USA) on 27 January 1973 for confirmatory diagnosis. Additional specimens were transported to the Veterinary Services Diagnostic Laboratory by South Dakota USDA/APHIS personnel on 29 January 1973. Gross and microscopic lesions were consistent with duck plague, and on 2 February 1973 the staff of the Reference Assistance Section reported the demonstration of typical herpesvirus particles by electron microscopy in sections of mallard liver material. Shortly thereafter the staff of the Virology Section, utilizing modifications of the procedure described by Jansen (1961), reported that 14 of 22 and eight of 15 duck embryos inoculated onto the chorioallantoic membranes with tissue suspensions from Lake Andes waterfowl 9 and 7 days earlier, respectively, had died. No significant mortality had occurred in chicken embryos inoculated concurrently by the yolk sac route with the tissue suspensions. On 12 February 1973 , based upon (1) neutralization of the virus isolated from the Lake Andes waterfowl by duck plague antiserum in both duck embryos and duck embryo fibroblast tissue cultures, (2) demonstration by electron microscopy of particles similar to the virion of duck plague and aggregation of these particles by duck plague antiserum, (3) the absence of pathogenicity of the virus in embryonated chicken eggs, (4) the failure of yolk sac material from infected duck embryos to agglutinate red blood cells, and (5) the demonstration of clinical signs and lesions typical of duck plague in inoculated ducks, the staff of the Virology Section reported that the virus isolated from the Lake Andes mallards and Canada geese had been identified as the causative agent of duck virus enteritis.

\section{Environmental conditions during the epizootic}

On 11 January the wintering mallard flock on the Lake Andes refuge was estimated at 100,000 birds, consisting of $70 \%$ males and $30 \%$ females (LANWRF). In addition, 9,000 Canada geese and small numbers of other waterfowl species were present (LANWRF). On the refuge, the ducks and geese used the open water on Owens Bay for drinking, bathing and resting, and the surrounding ice for loafing and roosting. Morning and afternoon feeding flights generally were made to harvested corn and sorghum fields in the area. When increased waterfowl losses were noticed in mid-January, ear corn was distributed on the shore of Owens Bay in an attempt to reduce the movement of exposed waterfowl from the refuge and on 20 January the flow from the well was diverted to an adjacent wetland to provide more open water area on the refuge. The Can- 
ada geese spent much of their time while on the refuge loafing on the ice, with small groups making periodic excursions to the open water to drink and bathe. The mallards also used the ice for loafing, but generally spent more time on the open water than did the geese. The area of open water on Owens Bay varied with the ambient temperature but typically encompassed 2 to 3 ha with a maximum depth of approximately $1.4 \mathrm{~m}$. Standard water chemistry analyses (chlorine, hardness, $\mathrm{pH}$, iron, phenolphthalein alkalinity, total alkalinity, $\mathrm{H}_{2} \mathrm{~S}, \mathrm{CO}_{2}$, dissolved $\mathrm{O}_{2}, \mathrm{NO}_{3}$, orthophosphate, $\mathrm{NH}_{3}, \mathrm{NH}_{4}$ and $\mathrm{NO}_{2}$ ) performed by VSDL on two water samples collected from Owens Bay on 16 February showed the constituents to be within accepted limits. On the Missouri River, the ducks and geese were dispersed in small flocks along the shores, on sand bars and on the open water and associated backwater areas which typically extended for more than 8 $\mathrm{km}$ below Fort Randall Dam.

Temperature and precipitation data prior to and during the epizootic were obtained from a National Weather Service station $11 \mathrm{~km}$ from Lake Andes at Pickstown (South Dakota, USA) (Table 1).

With the flow from the well diverted from Owens Bay, when the temperature dropped to $-13.9 \mathrm{C}$ on 28 January the open water area on the bay was reduced to 0.2 ha, and most ducks moved to the adjacent wetland where the diverted flow from the well maintained open water. Therefore, the flow from the well was diverted back to Owens Bay on 29 January, and, with warming temperatures, the open water area on the bay quickly re-expanded to 2 ha. On 8 February fewer than 100,000 mallards were estimated to be on the refuge and river, but that same day 40,000 mallards from the Lake Andes area were reported passing up the Missouri River at Pierre, South Dakota, $210 \mathrm{~km}$ northwest of the refuge. An aerial census conducted on 9 February showed an estimated 40,000 ducks and 850 Canada geese on the refuge and 45,000 ducks and 6,000 Canada
TABLE 1. Temperature ranges and precipitation in the Lake Andes, South Dakota, area prior to and during the 1973 duck plague epizootic.:

\begin{tabular}{|c|c|c|c|}
\hline \multirow[b]{2}{*}{ Date } & \multicolumn{2}{|c|}{ Temperature range (C) } & \multirow{2}{*}{$\begin{array}{c}\text { Precipitation } \\
\text { Snow }(\mathrm{cm})\end{array}$} \\
\hline & Low & High & \\
\hline 1 Jan & -16 & -1 & Trace \\
\hline 2 Jan & -8 & 3 & \\
\hline 3 Jan & -19 & 1 & Trace \\
\hline 4 Jan & -21 & -14 & 0.3 \\
\hline $5 \mathrm{Jan}$ & -24 & -12 & \\
\hline 6 Jan & -22 & -12 & Trace \\
\hline 7 Jan & -21 & -12 & 0.5 \\
\hline 8 Jan & -26 & -18 & 2.8 \\
\hline 9 Jan & -26 & -14 & \\
\hline 10 Jan & -2.3 & -7 & \\
\hline 11 Jan & -18 & -6 & \\
\hline $12 \mathrm{Jan}$ & -12 & 4 & Trace \\
\hline 13 Jan & -4 & 9 & \\
\hline $14 \mathrm{Jan}$ & 0 & 10 & \\
\hline $15 \mathrm{Jan}$ & -3 & 10 & \\
\hline 16 Jan & 2 & 1.3 & \\
\hline 17 Jan & -1 & 11 & \\
\hline 18 Jan & -3 & 8 & \\
\hline 19 Jan & -2 & -1 & \\
\hline $20 \mathrm{Jan}$ & -4 & -1 & \\
\hline 21 Jan & -4 & -1 & 9.9 \\
\hline 22 Jan & -10 & 0 & 3.8 \\
\hline 23 Jan & -12 & 6 & \\
\hline 24 Jan & -3 & 9 & \\
\hline $25 \mathrm{Jan}$ & -1 & $1: 3$ & \\
\hline 26 Jan & -2 & 8 & \\
\hline 27 Jan & -9 & -1 & 1.5 \\
\hline 28 Jan & -14 & -4 & 0.3 \\
\hline 29 Jan & -10 & 4 & \\
\hline 30 Jan & -7 & 8 & \\
\hline 31 Jan & -.5 & -1 & \\
\hline 1 Feb & -6 & 4 & \\
\hline $2 \mathrm{Feb}$ & -6 & 7 & \\
\hline $3 \mathrm{Feb}$ & -3 & 12 & \\
\hline $4 \mathrm{Feb}$ & -2 & 2 & \\
\hline $5 \mathrm{Feb}$ & $-\overline{3}$ & 1 & \\
\hline $6 \mathrm{Feb}$ & -12 & -2 & 0.5 \\
\hline $7 \mathrm{Feb}$ & -14 & -6 & 1.0 \\
\hline $8 \mathrm{Feb}$ & -16 & -3 & \\
\hline $9 \mathrm{Feb}$ & -13 & 0 & \\
\hline $10 \mathrm{Fel}$ & -11 & 4 & \\
\hline $11 \mathrm{Feb}$ & -2 & 8 & \\
\hline 12 Feb & -1 & 3 & 3.3 \\
\hline 13 Feb & -13 & -1 & 9.4 \\
\hline $14 \mathrm{Feb}$ & -18 & $-1: 3$ & 1.3 \\
\hline $15 \mathrm{Feb}$ & -21 & -14 & \\
\hline $16 \mathrm{Feb}$ & -27 & -11 & \\
\hline 17 Feb & -12 & 6 & \\
\hline 18 Feb & -11 & 8 & \\
\hline $19 \mathrm{Feb}$ & -1 & 4 & \\
\hline $20 \mathrm{Feb}$ & -.5 & 8 & Trace \\
\hline 21 Feb & -9 & 7 & \\
\hline 22 Feb & -1 & 11 & \\
\hline $23 \mathrm{Feb}$ & -6 & 17 & \\
\hline
\end{tabular}

a National Weather Service station (Pickstown. South 1)akotat. USA). 
geese on the Missouri River below Fort Randall Dam. When temperatures warmed to $15 \mathrm{C}$ on 23 February most of the waterfowl left the refuge during the day, leaving only scattered sick and dead ducks on Owens Bay.

On 3 February the first migrant waterfowl, approximately 5,000 Canada geese, arrived in the Lake Andes area. Two days later mallards and Canada geese were reported on the Missouri River $110 \mathrm{~km}$ above Fort Randall Dam. On 9 February 1973100,000 mallards were reported to have left the Kirwin National Wildlife Refuge (Kansas, USA) and to be arriving on the Platte River (Nebraska, USA) approximately $270 \mathrm{~km}$ south of Lake Andes. Waterfowl were reported on surrounding lakes and wetlands as open water appeared in the Lake Andes area on 21 February, and most of the mallards and Canada geese had left the Missouri River and were widely dispersed throughout the area when the first migrant northern pintails (Anas acuta) arrived on 23 February. The ice began to break up on Lake Andes on 6 March and a major influx of migrating diving ducks was observed on 8 and 9 March. By this time, most of the Canada geese, mallards, and migrant dabbling ducks had already left the area on their northward migration.

\section{Mortality}

Between 8 and 14 January, 200 duck carcasses were collected on the refuge, and by the time specimens were submitted to SDSU/VRDL on 19 January, the number had increased to 1,794 ducks (99\% mallards) and 20 Canada geese. When NPWRC and SDSU/VRDL personnel arrived at the refuge on 25 January, 4,319 duck carcasses and 29 goose carcasses had been collected. The extent and intensity of carcass searches varied with the number of personnel available and weather conditions (which periodically obscured some carcasses under snow and resulted in others being frozen in ice), so carcass collection figures do not necessarily reflect cor- responding waterfowl losses for those periods. However, daily searches from 29 January through 9 February generally resulted in 900 to 1,000 duck carcasses and one to eight goose carcasses being collected, with peaks of 2,060 duck carcasses and 15 goose carcasses collected on 30 January and 2,078 duck carcasses collected on 4 February. On 10 February, 1 mo after the onset of the epizootic, carcass collections on the refuge declined dramatically to $<300$ per day, despite the fact that an aerial census on 13 February showed 40,000 ducks and 3,000 Canada geese on the ice and 2 ha of open water on Owens Bay.

Duck plague mortalities diagnosed by gross or microscopic lesions were reported on six areas besides the refuge and the Missouri River after the ducks and geese dispersed from the refuge and the river in late February. Five of the areas were within an $11.25 \mathrm{~km}$ radius of the refuge, and the sixth (Red Lake, near Chamberlain, South Dakota, USA) was $90 \mathrm{~km}$ from the refuge. Four hundred sixty-eight duck carcasses and 47 Canada goose carcasses were found on these areas. The last known death was a female mallard found at Red Lake on 9 March.

Totals of 28,845 duck carcasses and 235 Canada goose carcasses were collected during the epizootic, including 22,122 ducks and 113 geese on the refuge, 6,255 ducks and 55 geese on the Missouri River, and 468 ducks and 47 geese on other wetlands in the area. The removal of carcasses by scavengers, the difficulty of locating carcasses in dense vegetation and the washing of carcasses downstream beyond the search area on the Missouri River combined to preclude a precise determination of the actual number of waterfowl that died in the epizootic. The reported mortality rates of $42 \%$ among the 100,000 mallards and 3\% among the 9,000 Canada geese at Lake Andes (Friend and Pearson, 1973a) was based on empirical assessments of the intensity of the searches and the visibility of waterfowl carcasses in different habitats. It was assumed that carcass 
collection was $90 \%$ efficient for ducks and 9.5\% efficient for Canada geese on the refuge, $40 \%$ efficient for ducks and $80 \%$ efficient for Canada geese on the Missouri River, and $20 \%$ efficient for ducks and $40 \%$ efficient for Canada geese on other wetland areas.

Although mallards comprised at least 99\% of the documented mortality during the epizootic, small numbers of other wild duck species also died. Based upon gross and in some cases microscopic lesions, duck plague was diagnosed in one or more American black ducks, American wigeon, wood ducks (Aix sponsa), redheads (Aythya americana), canvasbacks (Aythya valisineria), common goldeneyes, common mergansers, and pintail/mallard hybrids (Proctor et al., 1975). Duck plague was confirmed in a muscovy duck (Cairina moschata) found dead on the refuge early in the epizootic, and a Canada goose with a private aviculturist's band and a partially albino mallard, possibly a Pekin/mallard hybrid, died on the refuge during the epizootic. Although several northern pintails and buffleheads were present in the flock on Owens Bay, none was found dead during the epizootic.

Twenty banded Canada geese were found dead during the epizootic. Of 10 geese for which information was available from the BSFW Bird Banding Laboratory (Laurel, Maryland, USA), four had been banded in North Dakota (1969 to 1972), two each in South Dakota (1968, 1973) and Missouri (USA) (1966, 1968), one in Kansas (1971), and one had been banded in the Northwest Territories (Canada) (1964). Ninety-two banded mallards also were found dead during the epizootic. Of 54 for which information was available from the Bird Banding Laboratory, 23 had been banded in South Dakota (1963 to 1972), eight in Manitoba (1970 to 1972) and six in Saskatchewan (Canada) (1968 to 1972) and six in Kansas (1968 to 1972), three in Montana (1968 to 1971), two in North Dakota (1972), and one each in Nebraska (1964), Colorado (1972), Oklahoma
(1972), Illinois (1972), Indiana (1972) and New York (USA) (1971).

\section{Control measures}

Because duck plague, as an exotic disease, was under the jurisdiction of USDA and migratory birds were under the jurisdiction of USDI, the diagnosis of duck plague in the migratory waterfowl at the Lake Andes National Wildlife Refuge in 1973 raised the issue of which agency had jurisdiction over the epizootic.

After evaluating the situation on the refuge and the Missouri River, BSFW personnel at Lake Andes and from NPWRC and the local South Dakota Department of Game, Fish and Parks (SDDGFP; Pierre, South Dakota, USA) warden, who had extensive experience with the waterfowl in the area, concluded on 26 January that the most practical and effective control measure would be to shut down the well on Owens Bay. This would allow the bay to freeze over and facilitate dispersal of the waterfowl to the Missouri River where they would be more widely distributed and where contamination would be reduced by the water releases from Fort Randall Dam, thus reducing transmission of the virus. Meanwhile, at a meeting with BSFW officials in Washington, D.C., that same day, USDA officials recommended that actions be limited to placing the area under quarantine until confirmation of the diagnosis by virus isolation and identification could be made by the VSDL. Consequently, until the diagnosis was confirmed and the jurisdictional issue was resolved, control measures were limited to placing the refuge under quarantine to control the movement of infective materials from the refuge and to restrict the disturbance of waterfowl on the refuge, continuing carcass collection and storage in an open pile near Owens Bay, and continued monitoring of waterfowl movements and mortality at the refuge and on the Missouri River. Although final confirmation of the diagnosis was not made until 12 February, at a 5 February meeting, USDA officials in- 
formed BSFW that they were 95\% confident that the Lake Andes epizootic was duck plague, and that they preferred to defer their exotic disease jurisdiction in this case to the BSFW because migratory waterfowl were involved.

With migrant Canada geese that arrived in the Lake Andes area on 3 February and migrant ducks expected to arrive within 2 to 3 weeks, there was concern that transmission to additional susceptible waterfowl could prolong the epizootic and expose additional populations. Therefore, on $7 \mathrm{Feb}$ ruary officials from the Washington, D.C., and Denver (Colorado, USA) regional offices of the BSFW, animal control personnel from the BSFW's Denver Wildlife Research Center (Colorado, USA) and SDDGFP officials met with local BSFW and SDDGFP personnel at Lake Andes to review the situation and develop control measures. Because duck plague was classified as an exotic disease, consideration was first given to attempting to eradicate the exposed waterfowl flock. However, this was determined to be infeasible because exposed birds were not limited only to the refuge but they also were dispersed along $8 \mathrm{~km}$ of the river, making it improbable that more than $50 \%$ of the waterfowl could be killed. Shooting would have been ineffective and would have simply dispersed the waterfowl. The widespread availability of waste grain in area fields would have precluded trapping or the delivery of immobilizing agents or poisons to substantial numbers of the birds. Aerial application of contact poisons or detergents to the waterfowl on Owens Bay would have been ineffective because the waterfowl would have taken flight at the approach of aircraft. The application of oil or detergent to the open water on Owens Bay to disable the birds would have been possible, but probably would have affected a relatively small segment of the total population. In addition, a number of endangered bald eagles (Haliaeetus leucocephalus) was wintering in the area and feeding on disabled and dead waterfowl on the river and on the refuge. This precluded control measures that could have affected them. There also was concern that attempts to kill substantial numbers of the waterfowl would expedite the dispersal of exposed waterfowl from the Lake Andes area and increase the chance for them to transmit the disease to migrant populations.

The principal elements of the control program that was developed at the meeting included the following measures.

1. Maintaining the quarantine of the area.

2. Treating the open water of Owens Bay with calcium hypochlorite to reduce the level of duck plague virus contamination.

3. Treating the ice on Owens Bay with sodium carbonate to raise the $\mathrm{pH}$ of melt-water on the surface where fecal deposits in loafing and roosting areas created the potential for heavy virus contamination.

4. Continuing waterfowl carcass collection and initiating carcass disposal by incineration or burial.

5. Placing susceptible sentinel ducks on Owens Bay and the Missouri River to monitor exposure to duck plague virus on these areas.

6. Shutting down the well on Owens Bay, draining the bay, and chlorinating the water as it was discharged into the south unit of Lake Andes.

7. Burning the vegetation around Owens Bay to permit collection of hidden carcasses and expose the soil to sunlight.

8. Sampling the waterfowl population on the refuge to determine the prevalence of exposure and virus shedding, and banding and color marking the captured birds to permit monitoring of the flock's movements.

9. Dispersing the waterfowl from the refuge to the Missouri River.

10. Implementing surveillance through the spring migration to monitor waterfowl movements and mortalities along the flyway. 
Quarantine measures which already had been implemented included restricting public access to the refuge and establishing a quarantine line around the refuge that vehicles did not cross and where personnel entering the refuge donned coveralls and boots and removed them upon leaving. Before leaving the refuge, vehicles and equipment were pressure-washed and disinfected with a phenolic solution (Environ-D, Sanofi Animal Health, Inc., Overland Park, Kansas, USA). Boats and vehicles used in collecting carcasses on the Missouri River and other areas also were disinfected with the phenolic solution.

Prior to implementation of the control program, 10 wing-clipped, captive-raised sentinel mallards from NPWRC marked with colored nasal saddles had been released on Owens Bay on 1 February to gain information on virus transmission and the course of the disease. One of the sentinels was found dead and partially frozen on 8 February, evidence that it had died the previous day. Three more of the sentinel ducks were found dead on 10 and 11 February. All four had typical gross lesions of duck plague. Serum collected from one of the dead ducks was negative for duck plague virus neutralizing antibody in a serum neutralization (SN) test (Dardiri and Hess, 1967) conducted at the VSDL. Sera from four additional sentinel ducks recaptured on 10 and 11 February also were negative in $\mathrm{SN}$ tests and necropsy of three of these ducks revealed no evidence of duck plague. Because the dates on which sentinel ducks became infected are unknown, it is not possible to determine the actual incubation period and clinical course, but the period from infection until death appeared to have been $<1 \mathrm{wk}$. This is consistent with the reported incubation period ( 3 to 7 days) and clinical course ( 1 to 5 days) in domestic ducks (Leibovitz, 1991). In the wild mallards at Lake Andes, the disease also appeared to be very acute with a short incubation period and a clinical course of $<1$ day before death.

Chlorination of the open water on Ow- ens Bay was initiated on 8 February by mixing $\mathrm{Ca}(\mathrm{ClO})_{2}$ powder with water in large garbage cans using a small outboard motor, and then dispensing it from boats. Using this method, $3,182 \mathrm{~kg}$ of $\mathrm{Ca}(\mathrm{ClO})_{2}$ were applied to the open water of Owens Bay. The target level of 5 parts per million (ppm) of available chlorine in Owens Bay was not reliably achieved and the typical level of $3 \mathrm{ppm}$ reached during the day fell to $1 \mathrm{ppm}$ during the night when applications were suspended.

On 15 February drainage of Owens Bay was begun and the discharge was treated by bubbling $\mathrm{Cl}_{2}$ through the outflow to achieve a concentration of 2 to $3 \mathrm{ppm}$. A total of $3,182 \mathrm{~kg}$ of $\mathrm{Cl}_{2}$ had been used when the outflow stopped on 13 March. An additional $909 \mathrm{~kg}$ of $\mathrm{Ca}(\mathrm{ClO})_{2}$ were applied to the estimated $12.3 \mathrm{ha}-\mathrm{m}$ of water remaining in Owens Bay on 13 March.

Incineration of waterfowl carcasses collected on the refuge and from the river was begun on the refuge on 8 February using a portable propane incinerator. However, the capacity of the incinerator was limited, and after 21 February the remaining accumulated carcasses were hauled to municipal waste land fills at Pickstown and Mitchell (South Dakota, USA) where they were immediately buried.

On sunny days, solar heating caused the formation of melt-water puddles around waterfowl feces deposits (some containing blood) on the ice at Owens Bay, and waterfowl were observed dabbling in these puddles. Duck plague virus is reported to be inactivated at $\mathrm{pH}$ levels above 11 (Hess and Dardiri, 1968), so $29,091 \mathrm{~kg}$ of $\mathrm{Na}_{2} \mathrm{CO}_{3}$ were applied in a 0.3 to $0.6 \mathrm{~cm}$ layer on the ice at loafing and roosting sites on 10 February in an attempt to raise the $\mathrm{pH}$ of the melt-water and reduce virus concentrations in these areas.

It was determined that blood specimens and cloacal swabs would be necessary from at least $\mathbf{3 2 3}$ mallards from the Lake Andes flock in order to detect a $16 \%$ to $24 \%$ prevalence of infection at a $95 \%$ confi- 
dence level. Standing corn on the refuge was chopped to provide a feeding area for waterfowl, and 413 free-flying, clinically normal mallards from the Lake Andes flock were captured with cannon nets on 13 to 15 February. The ducks were banded, blood samples were obtained by jugular venipuncture, and cloacal swabs were collected. The dorsal surfaces of the primary wing feathers and tail feathers of the 91 mallards captured on 13 February were spray-painted with a fast-drying yellow paint, and 322 mallards captured on 14 and 15 February were similarly colormarked with a red paint to permit monitoring of subsequent movements of the flock.

The blood samples were centrifuged and the sera were collected. The serum samples and cloacal swabs were then transported to the USDA VSDL for duck plague $\mathrm{SN}$ testing (Dardiri and Hess, 1967) and virus isolation procedures (Jansen, 1961). Of 395 sera tested, 70 were positive at dilutions of $1: 4$, one was positive at $1: 8,28$ were positive at $1: 16$, one was positive at $1: 32,14$ were positive at 1 : 64 , two were positive at $1: 128$, four were positive at $\geq 1: 256$, and one was positive at 1:512. Therefore, $31 \%$ of the samples were positive at dilutions of $\geq 1: 4$, and $13 \%$ were positive at dilutions of $\geq 1: 16$. Duck plague virus was not isolated from any of the 345 captured normal mallards from which cloacal swabs were obtained.

Although control activities reduced the numbers of waterfowl on the refuge during the day after 8 February, the waterfowl generally returned at night. On the morning of 13 February, an estimated 43,000 waterfowl were on the refuge, and the following morning 15,000 ducks and 2,000 Canada geese were on the open water at Owens Bay. The well on Owens Bay was shut off on 17 February and active hazing of the waterfowl on the refuge was begun using plastic flags and propane exploders around Owens Bay throughout the day and night, and shell crackers fired from 12 gauge shotguns to disperse remaining wa- terfowl groups during the day. Grain in feed plots on several SDDGFP wildlife areas in the vicinity was chopped in a further effort to lure waterfowl away from the refuge. On 6 March water began flowing from around the base of the well when a leak developed in the well casing, so the well was re-opened and the flow was diverted directly into the south unit of Lake Andes where open water already had developed.

On 19 February, wing-clipped sentinel mallards color marked with nasal saddles were placed in enclosures near the well and near the outlet at Owens Bay and in an enclosure on a small tributary creek of the Missouri River which received heavy use by wild mallards. At the request of BSFW, the U.S. Army Corps of Engineers (Omaha, Nebraska, USA) increased the peak discharge from Fort Randall Dam to $2,982 \mathrm{~m}^{3} / \mathrm{sec}$ for $5 \mathrm{hr}$ on the night of 20 February to flush carcasses and fecal contamination from shorelines and sand bars on the river. Additional wing-clipped sentinel mallards with colored nasal saddles were released on the river on 21 February.

Two of five sentinel mallards placed near the well on Owens Bay developed duck plague $S N$ antibodies (1:32 and 1:64) and duck plague virus was isolated from cloacal swabs of three of 10 sentinels placed near the outlet; thus, significant virus contamination remained when the waterfowl were dispersed from the refuge on 17 February. Predation, especially by mink (Mustela vison), was high on the sentinel mallards on the river. No lesions of duck plague were found in one sentinel from the river or in two sentinels from the tributary creek found dead on 9 March. Duck plague virus was isolated from two of three live sentinel ducks from the tributary creek, but it is not known if the infections were the result of prior contamination of the area or of direct transmission from infected waterfowl after the sentinels were placed on the area on 19 February.

On 23 March when the propane exploders were removed, all of the ice was melt- 
ed on Owens Bay, leaving a small area of open water that could not be drained by the outlet water control structure. Therefore, on 25 May a ditch was blasted to drain the remaining water, and Owens Bay was completely dry on 28 June.

The vegetation around Owens Bay was burned on 6 April and only a few additional waterfowl carcasses were found. It is not known whether this was a reflection of a higher than anticipated rate of efficiency of carcass collection during the epizootic, a high rate of activity of scavengers, or both.

The BSFW field offices, state wildlife agencies, and the Canadian Wildlife Service were requested to report sightings of the red or yellow painted mallards from Lake Andes, and to monitor wild waterfowl populations through the spring and fall migrations and to report all significant mortalities. A brochure on duck plague and the Lake Andes epizootic describing the signs and gross lesions in mallards and Canada geese and providing instructions for collecting specimens and reporting suspected epizootics was prepared (Friend and Pearson, 1973a) and distributed to BSFW regional offices, state wildlife agencies and Canadian wildlife agencies.

Sightings of seven of the yellow marked mallards were reported from Alberta (Canada) and two were reported from Saskatchewan in April and May 1973. No duck plague mortalities were reported in association with the sightings of the color marked mallards, and none were reported in free-flying wild waterfowl during the remainder of 1973 and 1974 . However, sera collected from four wild ducks during an avian cholera epizootic in Texas (USA) in October 1973 were tested by VSDL and found to be positive for duck plague SN antibody at 1:8 dilutions. Duck plague epizootics were reported in captive waterfowl in Wisconsin (Jacobsen et al., 1976), Pennsylvania, Minnesota and New York (USA) in the spring of 1973, and in Alberta in the spring of 1974 (Hanson and Willis, 1976).

Eighty-three people, including news media personnel and visiting wildlife officials from other states and Canada, were on site during the Lake Andes epizootic, including $43 \mathrm{BSFW}$ personnel and 23 SDDGFP personnel. BSFW expenditures for the epizootic, including travel, overtime and holiday pay, supplies and equipment, were $\$ 33,940.78$.

\section{DISCUSSION}

\section{Diagnosis}

Despite the continuing speculation over other aspects of the Lake Andes epizootic, the diagnosis stands as one incontrovertible fact. Although virus isolation and identification were necessary in view of the exotic status of duck plague at that time, experience from the epizootic supports Leibovitz's (1991) statement that, "Complete gross lesions found at necropsy are diagnostic of duck plague. Histopathologic studies can further support these findings. The isolation and identification of the virus provide a confirmation even in the absence of diagnostic morphologic alterations."

Typical lesions of duck plague may not appear in all species of waterfowl (Leibovitz, 1971; Wobeser, 1987). However, when the full spectrum of characteristic gross lesions is displayed in species such as mallards and Canada geese as occurred at Lake Andes, a diagnosis of duck plague is warranted. Therefore, action on the diagnosis does not need to be delayed pending virus isolation and identification, or even histopathologic confirmation, except in cases where the absence of characteristic lesions makes the gross pathologic diagnosis uncertain.

\section{Environmental conditions during the epizootic}

The environmental conditions at Lake Andes in January 1973 were not considered by BSFW and SDDGFP personnel familiar with the area to be substantially different from previous winters, in terms of weather, food availability, waterfowl numbers, water conditions, waterfowl densities, or the occurrence of other diseases, and there had been no history of other ma- 
jor contagious disease epizootics in the waterfowl population at Lake Andes in the past. Therefore, no unique environmental factors were identified that might have triggered latent infections or virus shedding by carriers in 1973 if duck plague had been enzootic in the population previously. The acute nature of the epizootic and the high mortality in the mallards also are evidence that this population had no previous experience with the disease. Based on the evidence, we conclude that the unique variable in 1973 was the introduction of a virulent duck plague virus strain into this susceptible population of wild waterfowl. However, once the virus was introduced, waterfowl densities which historically had resulted in no significant disease losses now facilitated its rapid transmission within the flock.

\section{Origin of the infection}

Shortly after duck plague appeared in commercial duck flocks on Long Island in 1967, the disease was diagnosed in both captive ornamental and free-flying wild waterfowl, including American black ducks, mallards, Canada geese, a greater scaup (Aythya marila) and a bufflehead in the area (Leibovitz, 1968). Also, free-flying wild waterfowl were implicated in the transmission of the disease between commercial duck farms on Long Island and to captive waterfowl flocks in the region (Walker et al., 1969). Despite this Brand and Docherty $(1984,1988)$ stated that all confirmed epizootics of duck plague, including the one at Lake Andes, have involved commercial, captive-raised, avicultural, or nonmigratory waterfowl, and that the disease in migratory waterfowl occurs only in association with epizootics in such nonmigratory waterfowl.

Because the time and origin of duck plague virus introduction into the Lake Andes waterfowl population are not known, they have been topics of speculation. The population in January 1973 was composed principally of free-flying wild mallards and Canada geese with small numbers of American black ducks and several other species, including occasional buffleheads. The muscovy duck, the Canada goose with an aviculturist's band and the partially albino mallard, possibly a Pe$\mathrm{kin} / \mathrm{mallard}$ cross, found dead on the refuge during the epizootic provide the elements of captive-raised and avicultural waterfowl involvement. However, in considering the possible origins of duck plague virus at Lake Andes, it should be noted that factors that are common to both affected and non-affected populations are not ordinarily considered to have epizootiologic significance in themselves. Most wild waterfowl populations approaching the size of the one at Lake Andes probably include some escaped captive or feral waterfowl. Therefore, the mere presence of such birds in the flock does not demonstrate that they were the source of the infection, and their potential role must be evaluated on the basis of other evidence.

By early January, the wintering waterfowl population in the Lake Andes area probably was stable. Movements of birds would have been limited to traveling between the refuge and the river with feeding flights to harvested grain fields in the area, and without substantial influxes of waterfowl from other areas. Therefore, it seems reasonable to assume that the virus was introduced by a carrier(s) that had been in the population for at least a few weeks prior to the time the first losses were noticed on 13 January, rather than by the arrival in early January of waterfowl actively incubating the infection.

The muscovy duck found early in the epizootic was confirmed to have died of duck plague, but it appears to have been an unlikely candidate for introducing the virus into the Lake Andes flock. Muscovy ducks have been reported to be highly susceptible to lethal infections in natural duck plague epizootics (Gough, 1984). Although Burgess and Yuill (1981) reported the creation of Lake Andes strain virus carrier muscovy ducks by experimental contact exposure, Spieker et al. (1996) reported 
that muscovy ducks were more susceptible than mallards to virulent strains of duck plague virus. Therefore, it appears that the muscovy duck would have been less likely than a mallard to have survived a natural infection acquired elsewhere to become a carrier in the flock at Lake Andes. In addition, duck plague carrier waterfowl generally do not succumb to their infections (Burgess et al., 1979), as this muscovy duck did. Finally, prior to the Lake Andes epizootic, duck plague had been reported in the northeastern United States (Leibovitz, 1968) and in California (USA) (Snyder et al., 1973), but there had been no reports of duck plague in captive or domestic waterfowl in the local area. A feral or escaped captive muscovy duck seems to be an unlikely candidate to have migrated to South Dakota from the Atlantic or Pacific coast. Therefore, it appears that the muscovy duck was an incidental victim in the Lake Andes epizootic, rather than the source of introduction for the virus.

The same line of evidence indicates that the dead Canada goose with an aviculturist's band was a victim of the epizootic, rather than the source of the virus. Although a carrier state has been reported in Canada geese naturally infected with a less virulent duck plague virus strain, the geese did not succumb to their infections (Burgess et al., 1979). An escaped captive Canada goose also seems to be an unlikely candidate to have migrated to South Dakota from the Atlantic or Pacific coast where duck plague had been reported.

It is uncertain whether the dead mallard with white in its plumage was a partially albino wild mallard or Pekin cross. If it was a cross, it remains uncertain whether it was a captive or wild hatched bird. Therefore, it is difficult to evaluate its significance as a potential source of the virus. However, the same line of evidence suggests that, if this was a feral or escaped captive duck, it more likely was an incidental victim rather than the source of the infection.

The 9,000 wild Canada geese in the
Lake Andes area at the time of the epizootic must be considered as a possible source of the virus. However, because bands recovered from dead Canada geese found during the epizootic are evidence that they originated from areas in which duck plague had not been reported, there is no direct evidence to implicate them as the source of the infection.

A small number of American black ducks was present in the Lake Andes flock and several were found dead during the epizootic. Duck plague had been diagnosed in free-flying wild American black ducks in the northeastern United States prior to 1973 (Leibovitz, 1968). Shortly after the Lake Andes epizootic, duck plague was diagnosed in captive American black ducks on a Wisconsin game farm in April 1973 (Jacobsen et al., 1976). In the Wisconsin epizootic, the black ducks, which had been provided by the BSFW for the development of artificial propagation techniques, included 71 wild black ducks that had been captured the previous fall at the Crab Orchard National Wildlife Refuge (Illinois, USA) and 30 obtained from NPWRC 2 yr previously and 119 of their progeny (Jacobsen et al., 1976). In considering the origin of the infection on the game farm, the investigators identified free-flying wild waterfowl visiting the pens, a resident carrier black duck, or one of the black ducks captured at Crab Orchard as the possible sources (Jacobsen et al., 1976). However, the black ducks from NPWRC also had originally been obtained from Crab Orchard, and there was no evidence of duck plague in the NPWRC flock (all mortalities from which were necropsied routinely) before or after the black ducks were transferred to the Wisconsin game farm. Therefore, it appears unlikely that a resident carrier black duck was involved. However, if a resident carrier was involved, it apparently also would have originated from Crab Orchard. Jacobsen et al. (1976) emphasized that black ducks from the Atlantic Flyway occasionally visit the Crab Orchard Refuge, and that duck 
plague appeared to be enzootic in limited focal areas along the U.S. Atlantic coast. Because the virus isolated from the Wisconsin epizootic was less virulent than the Lake Andes strain (Burgess and Yuill, 1981), it probably was not introduced by a survivor of the epizootic at Lake Andes. Therefore, whether the virus was introduced by free-flying wild waterfowl or a carrier black duck captured the previous fall in Illinois, the epizootic in Wisconsin provides circumstantial evidence that duck plague was present in free-flying wild waterfowl in the upper midwestern United States prior to January 1973. In this context it is relevant to note that several American black ducks were present in the flock at Lake Andes. In addition one of the banded mallards found dead during the epizootic at Lake Andes had been banded in Illinois and another had been banded in Indiana, both in February 1972.

Only two or three possible feral or escaped waterfowl were observed in the flock at Lake Andes, but over 150,000 mallards and small numbers of other wild waterfowl, including American black ducks, were present in the flock. Therefore, on the basis of numbers alone, the probability of duck plague virus being introduced into the flock by wild waterfowl is substantially greater than of its being introduced by feral or escaped waterfowl.

Banding data from waterfowl found dead during the epizootic provide evidence that the flock at Lake Andes included Canada geese from four midwest states (USA) and the Northwest Territories of Canada, none of which had previous histories of duck plague. Alternatively, mallards in the flock included birds from 10 states (USA) and two Canadian provinces, thus making them more probable candidates for having migrated to South Dakota from areas where duck plague had occurred. The banded mallard from New York found dead during the epizootic was a female that had been captured in northern New York on 9 September 1971. Although she was not likely responsible for introducing the virus into the Lake Andes population herself, her presence indicates that other mallards from the northeastern United States probably also were present in the flock at Lake Andes. Duck plague had been diagnosed a number of times in mallards and other free-flying wild waterfowl in the northeastern United States, including New York, prior to 1973 (Leibovitz, 1968). Mallards also are reported to be among the more resistant species to duck plague (Jansen, 1968; Spieker et al., 1996) and carriers have been demonstrated in experimentally infected mallards (Burgess and Yuill, 1983). Therefore, although still circumstantial, the evidence implicating wild mallards as the source of duck plague virus introduction into the waterfowl population at Lake Andes in January 1973 includes the presence of a species (1) known to be more resistant to duck plague, (2) capable of becoming carriers after infection and (3) originating from an area where duck plague was known to have occurred. No other waterfowl or waterfowl species at Lake Andes in January 1973 met all three of these criteria.

In ranking the possible sources of the introduction of duck plague virus into the Lake Andes waterfowl population in January 1973 based upon the available evidence, we believe that carrier free-flying wild mallards from the northeastern United States appear to be the most probable source, followed by free-flying American black ducks or mallards from the upper midwestern United States, and then freeflying Canada geese from the midwestern United States. Escaped captive or nonmigratory waterfowl appear to be the least likely source.

Duck plague generally is presumed to have been introduced on North America shortly before it appeared in commercial Pekin duck flocks on Long Island in 1967. This presumption is based on the absence of reported cases of duck plague on North America prior to 1967 (Newcomb, 1968) and on the failure to detect significant duck plague antibody levels in 2,501 com- 
mercial waterfowl and 410 wild waterfowl sampled across the United States in 1967 (Dardiri and Hess, 1967) and in 3,000 commercial and migratory waterfowl sampled in 14 states in 1968 (Walker et al., 1969). However, serological surveys do not provide reliable information on the status of duck plague in waterfowl populations because duck plague antibodies may persist at detectable levels in infected birds for only a short time and many carrier waterfowl may have no detectable levels at all (Burgess et al., 1979; Burgess and Yuill, 1983). In addition, the significance of low level duck plague antibody titers is not known (Brand and Docherty, 1988).

Brand and Docherty (1984) collected cloacal and pharyngeal swabs for duck plague virus isolation from 3,169 migratory waterfowl across the United States in 1982 and 1983, from 1,033 waterfowl from seven areas of recurrent duck plague epizootics in nonmigratory and captive waterfowl in three states in 1983, and from 590 waterfowl captured at Lake Andes in 1982. Based on their failure to isolate duck plague virus from any of the samples, they concluded that the virus was not being shed or was being shed very infrequently $(<1$ shedder/500 birds) during the period tested. Although they acknowledged that it was difficult to determine what this lack of virus shedding meant relative to the status of duck plague in migratory waterfowl, they concluded that the results of their survey support the hypothesis that duck plague is not enzootic in North American migratory waterfowl. However, from an examination of the population dynamics of the waterfowl wintering at Lake Andes, it appears unlikely that duck plague carriers would still have been present at the rate of 1 shedder $/ 500$ ducks in 1982 . Assuming a uniform annual mortality rate of $44 \%$ among the 112,000 ducks surviving the 1973 epizootic, only 607 would be expected to remain in 1982. If it also is assumed that they returned to Lake Andes and the wintering duck population there in 1982 was the same size as in 1973 , these 607 survivors of the 1973 epizootic would have been present at a ratio of $\mathrm{P}=1 / 255$ ducks. The probability that the sample of 590 ducks tested in 1982 would have included at least one survivor of the 1973 epizootic is $90 \%\left(1-[1-\mathrm{P}]^{590}=0.90\right)$. However, it is not likely that all survivors of the 1973 epizootic became carriers. If it is assumed that the $31 \%$ of the survivors having duck plague antibodies became carriers, then $\mathrm{P}_{1}$ $=0.31 \mathrm{P}$ and the probability that the sample would have included at least one of them is $51 \%\left(1-\left[1-\mathrm{P}_{1}\right]^{590}=0.51\right)$. Of course, duck plague carriers shed virus only intermittently (Burgess et al., 1979), so the probability of the sample including a carrier actively shedding virus is less than $50 \%$. Therefore, there was a good chance that Brand and Docherty would not have detected duck plague carriers in the flock at Lake Andes at the low rate at which they probably occurred in 1982, and there was an even better chance that they would not have detected carriers in the other less extensively exposed waterfowl populations which they sampled.

During 1979-82, Brand and Docherty (1988) also sampled survivors of duck plague epizootics in urban and confined waterfowl at nine locations in the United States and they sampled free-flying waterfowl in the vicinities of four of those epizootics. They isolated duck plague virus from 24 of 724 urban and confined waterfowl and found duck plague antibodies in 71 of 842 of those waterfowl, but they failed to isolate duck plague virus from any of 870 free-flying waterfowl and found antibodies in only seven of 310 free-flying waterfowl in the vicinities of the epizootics. From this they concluded that there was no evidence of exposure to or shedding of duck plague virus in migratory waterfowl on the Eastern Shore of Maryland (USA) and in the vicinity of Sacramento, California (USA), where duck plague appears to be enzootic in urban and confined waterfowl. However, a review of their data does not show a clear differentiation between wild migratory waterfowl and non- 
migratory urban and captive waterfowl at the sites. For example, Brand and Docherty (1988) state that migratory waterfowl were free to mingle with the urban and confined waterfowl at eight of the nine locations. However, it is not possible for the reader to determine how many of the survivors which were sampled and from which duck plague virus was isolated or in which duck plague antibodies were found may actually have been migratory waterfowl using those sites. Where duck plague virus was isolated from a wild greenwinged teal (Anas crecca) at the Sacramento urban location, it is listed among survivors of epizootics in urban and confined waterfowl rather than with free-flying waterfowl in the vicinities of epizootics. Therefore, Brand and Docherty (1988) conclude that this "suggests the potential for wild birds to become infected and carry the disease to other wild populations." However, they do not address the alternative hypothesis that the wild greenwinged teal may have been infected prior to coming to the area and that it may have been responsible for carrying the disease to urban waterfowl. Similarly, mallards are included among the free-flying waterfowl sampled in the vicinities of all four epizootic locations without identifying whether they were migratory or nonmigratory. In addition, mallard hybrids, white Pekin ducks, a domestic goose and an unidentified swan were included among the freeflying waterfowl sampled at one location, so it is clear that not all of the free-flying waterfowl sampled were migratory birds. Brand and Docherty (1988) also state that mallard numbers fluctuated daily at an epizootic location in Michigan where duck plague antibodies were found in free-flying mallards, a white Pekin duck, and a bluewinged teal; they suggest that the mobility of urban mallards offered great potential for spreading duck plague. However, their data do not distinguish urban mallards from wild migratory mallards that may have been present at the site. Therefore, it also is difficult for the reader to deter- mine how many of the free-flying waterfowl sampled in the vicinities of the epizootic actually were wild migratory waterfowl and how many were nonmigratory waterfowl. Thus, despite the isolation of duck plague virus from a wild greenwinged teal at the Sacramento location and from a black duck at a location on the Eastern Shore of Maryland accessible to migratory waterfowl, Brand and Docherty (1988) conclude that there is no evidence of exposure to or shedding of duck plague virus in migratory waterfowl in either area. However, because their report does not differentiate clearly between wild migratory waterfowl and nonmigratory urban or confined waterfowl, its value in assessing the status of duck plague in free-flying wild waterfowl is limited.

The lack of convincing evidence that duck plague was not present on North America prior to 1967 warrants consideration of the possibility that it may have been enzootic in North American waterfowl prior to that time. One line of evidence supporting this hypothesis is the isolation within $16 \mathrm{yr}$ after 1967 of several strains of duck plague virus of widely varying virulence from North American waterfowl. These included the highly virulent Lake Andes strain and five less virulent strains isolated from 1973 to 1976 (Spieker et al., 1996) and the nonpathogenic Sheridan-83 strain isolated in 1983 (Lin et al., 1984). However, nearly 4 decades after duck plague appeared in the Netherlands, only two different strains of the virus had been recognized there (Jansen, 1961). If duck plague was an exotic disease on North America in 1967, it seems improbable that so many different strains would have developed in such a short time period.

Leibovitz and Hwang (1968) doubt that the 1967 epizootic in commercial Pekin duck flocks on Long Island represents the first occurrence of duck plague on North America and suggest it is more likely that the maintenance of these large numbers of susceptible domestic waterfowl under 
close veterinary monitoring simply enhanced the opportunity for its detection. Leibovitz (1968) contrasts this "extremely sensitive system for monitoring the presence of anatine diseases" with disease recognition in wild waterfowl which frequently is based on the chance observation of more obvious epizootics and where field conditions commonly present obstacles to diagnosis. This is further complicated by the absence of typical gross lesions of duck plague in some wild waterfowl species (Leibovitz, 1971; Wobeser, 1987). In addition, gross lesions such as petechial and ecchymotic hemorrhages on the myocardium and focal necrosis of the liver may occur in both duck plague (Leibovitz, 1991) and avian cholera (Botzler, 1991), and this could lead to misdiagnoses in the field, especially in areas with prior histories of avian cholera epizootics.

Two undiagnosed epizootics in wild waterfowl on the Platte River (Nebraska, USA) in 1950 and 1964 also raise the possibility that duck plague may have been enzootic in wild waterfowl on North America prior to 1967. Avian cholera was suspected in both epizootics and specimens from the 1964 epizootic were examined by experienced USFWS diagnosticians at the Patuxent Wildlife Research Center and the Bear River Research Station (Brigham City, Utah, USA), but Pasteurella multocida could not be isolated and the cause of the epizootic was not determined (Friend, 1984). However, duck plague was unknown on North America at that time and neither laboratory was equipped for duck plague virus isolation. Subsequently, Friend (1984) reported that, "A review of the correspondence between individuals involved in these outbreaks provides strong evidence that the 1964 die-off was not avian cholera and creates serious doubt that this was the cause of the 1950 die-off." The intervals between these epizootics and the 1973 epizootic at Lake Andes are consistent with the long interval between the epizootic at Lake Andes and the next major duck plague epi- zootic in wild waterfowl on the Finger Lakes in 1994. Of course, if either of these earlier epizootics on the Platte River was duck plague, it not only would mean that the disease was enzootic in migratory waterfowl on North America prior to 1967, but it would further increase the probability that the virus was introduced into the flock at Lake Andes in 1973 by infected migratory waterfowl.

\section{Mortality}

Estimating the waterfowl mortality in the Lake Andes epizootic was complicated, not only by uncertainties regarding the efficiency of carcass collections at the various sites, but also by the difficulty of establishing an accurate estimate of the total population at risk. Waterfowl were variously dispersed among sites on the refuge, $8 \mathrm{~km}$ of the river and scattered feeding fields, with dynamic interchange occurring among the areas. Therefore, it was difficult to obtain an accurate count of the entire population. Because the 100,000 mallards estimated to be on the refuge on 11 January did not include those on the river, it is virtually certain that the total population at risk in the epizootic was substantially greater than 100,000. For example, 100,000 mallards were estimated to be on the refuge on 11 January, and 30,000 to 40,000 were estimated to be on the river on 26 January. This suggests that the total mallard population at risk may actually have been 140,000 . The total estimated mortality of 42,553 ducks and 327 Canada geese reported by Friend and Pearson (1973b) was based on assumed carcass collection efficiencies and not on the population at risk. Thus, changes in the population at risk would not change the estimated absolute mortality, but they would change the estimated mortality rate in the populations.

The reported mortality of $42 \%$ among 100,000 mallards at Lake Andes (Friend and Pearson, 1973a) was based upon an estimated total mortality of 42,553 ducks, $99 \%$ of which were estimated to be mal- 
lards. The estimated 42,127 mallard mortality included 24,334 on the refuge, 15,477 on the Missouri River and 2,316 from other areas. However, the $42 \%$ mortality was derived by comparing the total estimated mortality from all areas with the estimated 100,000 mallards on just the refuge. If the estimated 24,334 mallard mortality on the refuge is compared with the 100,000 mallards on the refuge, the mortality is $24 \%$ instead of $42 \%$. Therefore, in order to determine the mortality rate for the epizootic at Lake Andes, it is necessary to compare the total mortality with the total population at risk during the epizootic.

Although estimates of different segments of the waterfowl population (refuge, river, or outlying areas) were made at various times during the epizootic, the only comprehensive surveys of the entire Lake Andes population were those done on 8 and 9 February. On 8 February 40,000 mallards left the Lake Andes area and moved up the Missouri River, and based on an aerial survey on 9 February, an estimated 85,000 mallards remained, including 45,000 on the river and 40,000 on the refuge. However, by 9 February 18,917 duck carcasses also had been collected. Thus, based upon a composite carcass recovery efficiency of $68 \%$ from all areas, this would project to an estimated 28,000 additional dead mallards. Therefore, the total mallard population at risk in the Lake Andes area during the peak of the epizootic in late January and early February appears to have been 153,000 . Adding another $1 \%$ for other species brings the duck population at risk to 154,500 birds.

It is evident that the mortality in the epizootic at Lake Andes was substantially lower than the frequently cited $42 \%$ (Friend and Pearson, 1973a, 1973b, Jacobsen et al., 1976; Brand and Docherty, 1984, 1988; Leibovitz, 1991). Based on the evidence available, the documented mortality among ducks $(28,845$ carcasses collected) was $19 \%$. The estimated mortality for the total mallard and total duck populations at risk in the epizootic was $28 \%$.
The documented mortality among Canada geese based on 235 carcasses collected was $<3 \%$. Because the Canada goose population was smaller, population estimates $(7,000$ and 9,000$)$ were consistent, carcass recovery rates were high, and the total estimated mortality was compared with the total population at risk, the $3 \%$ reported mortality for Canada geese in the Lake Andes epizootic (Friend and Pearson, $1973 b$ ) is increased only slightly to $<4 \%$.

The documented mortality among all 163,500 waterfowl $(154,500$ ducks and 9,000 Canada geese) at risk at the onset of the epizootic was $18 \%$. The estimated mortality was $26 \%$.

\section{Control measures}

It was not possible to quantify specifically the efficacy of each of the control measures implemented. Any assessment must be tempered by the recognition that epizootics are finite events that terminate spontaneously as susceptible hosts are eliminated. Jansen (1968) reported that in duck plague epizootics involving high mortality in domestic ducks, mortalities continued for about 3 wk. In the epizootic at Lake Andes, there were indications that the mortality was beginning to decline 1 mo after it started, just as the control program was being implemented. Still, some generalizations may be warranted.

The quarantine and disinfection measures appear to have been justified, and not simply because duck plague was classified as an exotic disease by USDA. Because many BSFW and SDDGFP personnel and vehicles were involved, it was only prudent to attempt to reduce the potential for fomite transmission of the virus to other areas. Although the duration of survival of duck plague virus in decomposing waterfowl carcasses is not known, carcass collection and disposal also appeared to be warranted in order to avoid decoying unexposed waterfowl to heavily contaminated areas and to reduce the overall level and duration of virus contamination of the 
environment. In addition, carcass collection permitted monitoring of mortality.

In view of the reported greater susceptibility of Canada geese to duck plague (Spieker et al., 1996), the relatively low $<4 \%$ mortality in the Canada geese compared with the $28 \%$ mortality in mallards is evidence for a significant difference in the exposure of the two species at Lake Andes. The most apparent behavioral difference that might explain such an exposure differential was the greater proportion of time that the mallards spent on the water at Owens Bay compared with the time spent on the surrounding ice. This is consistent with the commonly reported observation that water appears to be the natural means of transmission of duck plague virus from infected to susceptible waterfowl (Leibovitz, 1991). It also suggests that the first priority in programs to control epizootics in wild waterfowl should be to eliminate or reduce their access to water areas contaminated with the virus. For example, in the absence of other control measures at Lake Andes, simply shutting off the well and allowing Owens Bay to freeze while allowing the ducks and geese to continue using the ice for loafing and roosting might have kept mortalities to an acceptably low level until the waterfowl dispersed naturally to surrounding areas on 23 February.

The efficacy of the chlorination of Owens Bay appears to have been limited. This was demonstrated by the failure to maintain the target level of 3 to $5 \mathrm{ppm}$ available chlorine. Also, there were duck plague antibodies and virus in sentinel mallards placed on Owens Bay 11 days after the initiation of chlorination. The abundance of organic material in the marsh environment of Owens Bay may have contributed substantially to the inability to maintain the target level of chlorine. The lower level of available organic material in the water drained from Owens Bay permitted more effective chlorination of the outflow. Wolf and Burke (1982) reported that raw water from Owens Bay experimentally seeded with duck plague virus and held at $4 \mathrm{C}$ retained about $0.1 \%$ of its infectivity after 30 days and about $0.01 \%$ of its infectivity after 60 days. Therefore, it appears that any benefits of chlorination were limited primarily to an immediate incremental reduction in duck plague virus in water drained from Owens Bay into the south unit of Lake Andes. However, it is not known how significantly this may have reduced the actual hazard posed to waterfowl using the lake. Because so little is known about the persistence of duck plague virus in natural environments, it was felt necessary to attempt chlorination of the water and to drain Owens Bay. However, in retrospect it appears that earlier dispersal of the waterfowl from Owens Bay coupled with measures to restrict waterfowl use of the area until virus levels declined naturally would have been more cost and labor efficient, and probably more effective.

Attempting to inactivate accumulated virus on the ice at Owens Bay by applying sodium carbonate to raise the $\mathrm{pH}$ of meltwater on the surface was difficult and probably of limited value. Preventing the development of high levels of virus contamination on the ice by earlier dispersal of the waterfowl undoubtedly would have been more efficient and effective.

Duck plague virus is reported to lose its infectivity after 30 days at room temperature (Hess and Dardiri, 1968). Although the duration of infectivity of duck plague virus in soil and vegetation has not been reported, it seems unlikely that significant levels of infective virus would have persisted in the area until waterfowl returned the following fall and winter. Therefore, burning the vegetation around Owens Bay probably provided only limited short-term benefits over allowing decontamination to occur naturally. Like other measures to reduce virus contamination of the environment, burning of vegetation should be assigned a lower priority than preventing contamination in the first place.

After the onset of winter, the waterfowl 
at Lake Andes were relatively isolated from other major wintering waterfowl populations. Thus, the opportunity for the introduction of contagious diseases may actually have been lower than for waterfowl wintering in other areas where interchange among populations is greater. However, when a highly contagious and virulent agent was introduced, the high density of susceptible hosts, consisting of 100,000 mallards and 9,000 Canada geese using 2 to 3 ha of open water and surrounding ice at Lake Andes, provided conditions conducive to rapid transmission and high mortality.

It is important to recognize that, at the same time that the Lake Andes area provided the high number and density of susceptible waterfowl favorable to the development of an epizootic when duck plague virus was introduced (Leibovitz, 1968), it also provided conditions uniquely suited to control of the epizootic that did develop. Although over 100,000 waterfowl were congregated on 2 to 3 ha of open water and the surrounding ice on Owens Bay, only $11 \mathrm{~km}$ away was the Missouri River with $8 \mathrm{~km}$ of open water and flows averaging $1,859 \mathrm{~m} 3 / \mathrm{sec}$. Not only did the limited area at Owens Bay permit effective dispersal of the flock from the site, but the birds could be dispersed with virtual assurance that they would simply shift to the Missouri River. They were already accustomed to that area and would not mix with other waterfowl populations. The cycle of water releases for hydroelectric power generation at Fort Randall Dam on the Missouri River ranged from 0 to $3,253 \mathrm{~m}^{3}$ / sec. This created exposed shorelines and sand bars used by the waterfowl, and then provided massive flushing and dilution of contamination of those areas on a daily basis. Thus, the Lake Andes area simultaneously provided conditions ideal for transmission of a highly contagious pathogen when it was introduced, and ideal for limiting transmission when it occurred. However, it also supports the necessity for evaluating duck plague epizootics on a case-by-case basis and tailoring control measures specifically to each situation.

Although mortalities occurred on the Missouri River and increased after the waterfowl were dispersed from Owens Bay, these appear to have been primarily birds that had been exposed at Owens Bay. Because infection occurred in sentinel mallards placed on a tributary of the river that had been heavily used by mallards and mortalities continued to occur in the general area for $3 \mathrm{wk}$ after the birds were dispersed from Owens Bay, this is evidence that transmission did occur off the refuge. However, transmission apparently was not at a sufficient rate to sustain the epizootic.

Resolution of the jurisdictional questions involved in dealing with a disease classified as exotic by USDA delayed implementation of a comprehensive control program for the epizootic at Lake Andes. However, it is interesting and perhaps instructive for future reference to speculate as to what might have happened if the well at Owens Bay would have been shut off and the waterfowl dispersed from the bay on 26 January after the diagnosis was made at the refuge. By 26 January 5,373 waterfowl carcasses had been collected on the refuge and only a few were found on the river. Assuming a $90 \%$ efficiency of collection, these reflected an estimated total mortality of $5,970(3.7 \%)$ of the 163,500 total waterfowl population at risk. If an incubation period of 6 days and a clinical course of 1 day are assumed, then the deaths occurring over the subsequent 7 days reflect the waterfowl that were exposed on or prior to 26 January. By 2 February 11,548 waterfowl carcasses had been collected, reflecting an estimated mortality of $12,831(8 \%)$ of the waterfowl population at risk. Therefore, it appears that if the control measures had been implemented at the time when the pathologic diagnosis was made, the mortality rate in the epizootic at Lake Andes might have been on the order of $8 \%$, instead of the estimated $26 \%$ that occurred. Thus, we suggest that over two-thirds of the mortal- 
ity in the Lake Andes epizootic may be attributed to the delay in implementing control measures.

\section{Implications for wild waterfowl}

The rapidly escalating mortality of an exotic disease in a large free-flying wild waterfowl population on a national wildlife refuge made the loss of nearly 43,000 ducks and geese in the duck plague epizootic at Lake Andes a sensational wild waterfowl disease event. However, another perspective is to consider the mortality in terms of its relative and absolute impacts on wild waterfowl populations.

The annual natural mortality in free-flying wild ducks has been estimated to be 22.2\% (Sanderson and Bellrose, 1986). In mallards the natural mortality and hunting mortality each is responsible for approximately one half of the total annual mortality (Anderson, 1975). Therefore, in the North American 1996 fall population of $80,000,000$ ducks, the loss of 42,500 ducks is the equivalent to $0.12 \%$ of the $35,520,000$ total annual mortality, and in the 1996 fall mallard population of $8,000,000$, the loss of 42,000 birds is equivalent to $1.2 \%$ of the $3,552,000$ total annual mortality.

Between 1934 and 1970, botulism is estimated to have caused an annual average loss of 40,000 wild waterfowl in California alone, and the 1968 and 1969 epizootics in the Sacramento and San Joaquin valleys (California, USA) are estimated to have killed 250,000 waterfowl (Hunter et al., 1970). Avian cholera is reported to have killed 60,000 wild waterfowl in Texas in 1956 and 1957 (Jensen and Williams, 1964), 70,000 in California in 1965 and 1966 (Rosen, 1972) and 70,000 to 100,000 in Nebraska in 1980 (Friend, 1984), and annual losses in California alone are reported to average 10,000 to 25,000 waterfowl (Botzler, 1991). By way of comparison, in addition to incidental losses associated with the 1967 epizootic in commercial ducks on Long Island (Leibovitz, 1968) and other isolated mortalities such as the one reported by Wobeser and Docherty (1987), three epizootics of duck plague have been reported in free-flying wild waterfowl. Since the disease was first recognized on North America, there has been an epizootic at Flanders Bay in 1967 (Leibovitz, 1968), the second epizootic was at Lake Andes in 1973, and the third occurred on the Finger Lakes in 1994 (Friend and Cross, 1995). The combined reported mortality in these epizootics was approximately 45,000 waterfowl.

Chronically infected carriers that intermittently shed virus for up to $4 \mathrm{yr}$ have been reported in captive black ducks and Canada geese surviving a natural duck plague epizootic. Also, chronically infected carriers have been produced in experimentally infected mallards and several other waterfowl species (Burgess et al., 1979). Duck plague carrier mallards remain apparently healthy, intermittently shed virus, and may have no detectable SN antibodies (Burgess and Yuill, 1983). Although duck plague virus was not isolated from cloacal swabs obtained from 345 of the clinically normal mallards captured at Lake Andes in mid-February 1973, duck plague $\mathrm{SN}$ antibodies were demonstrated in sera from $13 \%$ to $31 \%$ (depending on the interpretation of low titers) of 395 of the mallards. Because the mallards were captured as waterfowl deaths had begun to decline, this suggests that $13 \%$ to $31 \%$ of the survivors of the epizootic had been exposed to duck plague virus and had the potential to become carriers. With an estimated 112,000 ducks in the population of 154,500 surviving the epizootic, it appears that as many as 14,000 to 34,000 potential duck plague carriers may have left the Lake Andes area. However, because not all carriers develop $\mathrm{SN}$ antibodies, this probably represents a conservative estimate of the number of potential carriers among the survivors of the epizootic.

Band returns demonstrate that mallards from Lake Andes disperse to 26 states in all four major flyways of the United States as well as to four Canadian provinces. 
Therefore, it appears incontrovertible that a massive infusion of duck plague carriers occurred into the wild waterfowl populations of all four flyways as a result of the epizootic at Lake Andes. Consequently, rather than providing evidence that duck plague is not enzootic in wild waterfowl populations, the absence of duck plague epizootics in wild waterfowl for 2 decades following 1973 is evidence that substantial numbers of duck plague carriers can occur in wild waterfowl populations without resulting in major mortalities. Indeed, the absence of major duck plague epizootics in wild waterfowl between 1973 and 1994 despite the occurrence of large waterfowl concentrations in many areas is evidence that such epizootics are unique phenomena rather than the normal situation for the disease in free-flying wild waterfowl. This also indicates that the epizootiology of duck plague in wild waterfowl may be similar to that outlined for avian cholera by Botzler (1991). He suggested that introductions into susceptible populations may be common, resulting in only a few losses that are not detected. However, under the proper conditions, these may flare into extensive epizootics. The occurrence of sporadic, isolated cases of duck plague in wild waterfowl such as reported by Wobeser and Docherty (1987) and the 1994 epizootic on the Finger Lakes (Friend and Cross, 1995) provide further support for such an hypothesis. The alternative hypothesis is that a duck plague virus carrier state does not develop or persist in free-flying wild waterfowl and that infections in wild waterfowl end with the termination of epizootics. The disease is precluded from becoming enzootic and this reduces its potential impacts on wild waterfowl populations. Consequently, after tens of thousands of potentially exposed waterfowl left Lake Andes in 1973, it appears that duck plague either is established as an enzootic disease in wild waterfowl, or that it is not likely to become so.

The inability to isolate duck plague virus from serologically positive mallards col- lected during this major epizootic raises serious questions concerning the validity of conclusions regarding the status of duck plague in wild waterfowl based upon negative results of random surveys of wild waterfowl populations conducted in the absence of epizootics. Clearly, if virus was not isolated from a population in which $13 \%$ to $31 \%$ of the waterfowl were known to have been recently exposed to duck plague virus, more reliable methods will have to be developed before the actual status of duck plague can be determined in free-flying wild waterfowl populations where carrier rates as low as $0.001 \%$ could represent significant enzootic infection.

\section{Recommendations for future studies}

Waterfowl diseases are unique among animal diseases because of the dynamic interactions that occur within and between the different components of the continental population. Free-flying wild waterfowl make semi-annual migrations that span the length and breadth of the North American continent, and some migrate to and from South America. In their travels, free-flying wild waterfowl not only mingle with other wild waterfowl, but they have frequent contacts with domestic, feral and captive waterfowl flocks. Therefore, unlike most other wildlife diseases where the different classes of hosts tend to be restricted in their movements and contacts, waterfowl diseases must be viewed in the context of a cosmopolitan continental host population consisting of multiple interacting components, rather than as discrete migratory, domestic, captive and feral populations.

The limitations of serology and virus isolation in identifying duck plague carriers will require the utilization of other techniques to monitor the status of duck plague in waterfowl populations. The use of polymerase chain reaction techniques for identifying duck plague carriers and latent infections should be investigated. Duck plague virus DNA analysis and fingerprinting of the original Holland and 
Long Island strains, the Lake Andes strain and the other strains isolated from migratory, feral and captive waterfowl since 1967 perhaps has the greatest potential for identifying their relationships and resolving the question of the status of duck plague in free-flying wild waterfowl.

Carriers undoubtedly play a central role in maintaining and transmitting duck plague virus in waterfowl populations. Further investigations of the carrier state to determine patterns and levels of virus shedding with different virus strains and in different waterfowl species and establishment of levels of virus shedding required for transmission would be helpful in understanding the epizootiology of the disease.

A retrospective epizootiologic analysis of duck plague epizootics in North American waterfowl over the past $30 \mathrm{yr}$ could yield information on factors common to epizootics and on potential sources of introduction of the virus. In future epizootics, epizootiologic investigations should receive equal emphasis with diagnosis and control, and the efficacy of control measures should be evaluated objectively. Although duck plague epizootics most commonly occur in the spring (Brand, 1987), the three epizootics in free-flying wild waterfowl (Flanders Bay, Lake Andes and Finger Lakes) have occurred in the winter. This suggests that the epizootiology of duck plague in migratory waterfowl may differ substantially from that in captive and feral waterfowl. Investigations should focus on identifying the factors common to epizootics in migratory waterfowl. Botzler (1991) notes that the apparent sudden onset of avian cholera among wild waterfowl coincided with a period of extensive human-associated changes in the environment, and these same changes may also be related to the sudden recognition of duck plague among North American waterfowl.

A chicken embryo-adapted modified live virus duck plague vaccine has been used successfully to control the disease in domestic ducks (Leibovitz, 1991), as well as in a zoological collection (Montali et al., 1976), but it has not been authorized for use in wild or avicultural waterfowl (Leibovitz, 1991). With molecular engineering technology available, it seems probable that a safe and effective duck plague vaccine could be developed for use in game farm, avicultural and even selected feral waterfowl to reduce the pool of susceptible birds. Vaccination of game farm waterfowl could, for example, make it possible to release waterfowl less susceptible to duck plague than the free-flying wild waterfowl with which they might associate before and after release. In addition, the nonpathogenic but immunogenic Sheridan-83 strain (Lin et al., 1984) could have potential for immunizing free-flying wild waterfowl.

\section{ACKNOWLEDGMENTS}

The extensive diagnostic and technical support provided by $M$. Vorhies, $H$. Shave and the staff of the South Dakota State University Veterinary Research and Diagnostic Laboratory is gratefully acknowledged. At the USDA Veterinary Services Diagnostic Laboratory, S. J. Proctor performed light and electron microscopic examinations of tissues from the waterfowl, J. E. Pearson performed the virus isolation and identification studies, and R. Harrington, Jr., and D. C. Hulse performed bacteriologic examinations. M. Friend assisted in the sentinel studies, specimen collection, data collection and compilation, photographic documentation, informational activities and development of control measures. L. Locke provided diagnostic assistance and R. Kocan assisted in specimen collections. S. Berlinger, A. Radtke, T. Stone and the staff of the Lake Andes National Wildlife Refuge provided unlimited logistical support and graciously opened their offices and files to an invasion of disease control and administrative personnel. U.S. Game Agents D. Fisher and $H$. Lovrien, SDDGFP warden $L$. Nelson and BSFW biologist W. Bair provided invaluable assistance with their extensive knowledge of the waterfowl in the area. BSFW pilot J. Pospichal conducted aerial waterfowl surveys. H. Willoughby, C. Sowards and $H$. Stiles provided administrative expertise to expedite the control program. Many other BSFW and SDDGFP personnel put in long days under difficult conditions to monitor waterfowl flocks, collect and dispose of carcasses and implement other aspects of the control program. 
D. Johnson advised on statistical analyses. W. R. Goforth, L. Leibovitz and L. Sileo reviewed the manuscript and provided many constructive comments.

\section{LITERATURE CITED}

ANdersoN, D. R. 1975. Population ecology of the mallard. V. Temporal and geographic estimates of survival, recovery, and harvest rates. U.S. Fish and Wildlife Service Resource Publication 125 , Washington D.C., $110 \mathrm{pp}$.

BAUDET, A. E. R. F. 1923. Mortality in ducks in the Netherlands caused by a filterable virus; fowl plague. Tijdschrift Diergeneeskunde 50: 455459.

BOTZLER, R. G. 1991. Epizootiology of avian cholera in wildfowl. Journal of Wildlife Diseases 27: 367395.

Brand, C. J. 1987. Duck plague. In Field guide to wildlife diseases. Volume 1. General field procedures and diseases of migratory birds, $\mathbf{M}$. Friend (ed.). U.S. Department of the Interior, Fish and Wildlife Service, Resource Publication 167, Washington, D.C., pp. 117-127.

BraNd, C. J., AND D. E. DOCHERTY. 1984. A survey of North American migratory waterfowl for duck plague (duck enteritis) virus. Journal of Wildlife Diseases 20: 261-266.

— AND —. 1988. Post-epizootic surveys of waterfowl for duck plague (duck virus enteritis). Avian Diseases 32: 722-730.

Burciess, E. (.., J. OSSA, AND T. M. YULL.. 1979. Duck plague: A carrier state in waterfowl. Avian Diseases 24: 940-949.

—, AND T. M. YUILL. 1981. Vertical transmission of duck plague virus (DPV) by apparently healthy DPV carrier waterfowl. Avian Diseases 25: 795-800.

198.3. The influence of seven environmental and physiological factors on duck plague virus shedding by carrier mallards. Journal of Wildlife Diseases 19: 77-81.

DARDIRI, A. H., AND W. R. HFss. 1967. The incidence of neutralizing antibodies to duck plague in serums from domestic ducks and wild waterfowl in the United States of America. In Proceedings of the 71 st Meeting, United States Livestock Sanitary Association, Richmond, Virginia, pp. 225-237.

Devos, A., N. ViakNe, AND H. Staelens. 1964. Duck plague in Belgium. Vlaams Diergeneeskunde Tijdschrift 33: 260-266.

FriEND, M. 1984. Waterfowl get sick, too. In Flyways, pioneering waterfowl management in North America, A. S. Hawkins, R. C. Hanson, H. K. Nelson and H. M. Reeves (eds.). U.S. Department of the Interior, Fish and Wildlife Service. U.S. Government Printing Office, Washington, D.C., pp. 478-485.
—, AND D. H. Cross. 1995. Waterfowl diseases: Causes, prevention, and control. Waterfowl Management Handbook 13. U.S. Department of the Interior, National Biological Service, Washington, D.C., 8 pp.

$\longrightarrow$, And G. L. Pearson. 1973a. Duck plague (duck virus enteritis) in wild waterfowl. U.S. Department of the Interior, Bureau of Sport Fisheries and Wildlife. U.S. Government Printing Office, No. 2410-00372, Washington, D.C., 16 pp.

$\longrightarrow$, AND $\longrightarrow$ 1973b. Duck plague: The present situation. In Proceedings of the 53rd Annual Conference of the Western Association of State Game and Fish Commissioners, Salt Lake City, Utah, pp. 315-325.

GouGH, R. E. 1984. Laboratory confirmed outbreaks of duck virus enteritis (duck plague) in the United Kingdom from 1977 to 1982. The Veterinary Record 114: 262-265.

—, AND D. J. Alexander. 1990. Duck virus enteritis in Great Britain, 1980 to 1989 . The Veterinary Record 126: 595-597.

Hall, S. A., AND J. R. Simmons. 1972. Duck plague (duck virus enteritis) in Britain. The Veterinary Record 90: 691.

Hanson, J. A., AND N. G. Willis. 1976. An outbreak of duck virus enteritis (duck plague) in Alberta. Journal of Wildlife Diseases 12: 258-262.

Hess, W. R., AND A. H. DARDiRi. 1968. Some properties of the virus of duck plague. Archiv für die Gesamte Virusforschung 24: 148-153.

hunter, B. F., W. E. Clark, P. J. Perkins, and P. R. Coleman. 1970. Applied botulism research including management recommendations. A progress report. California Department of Fish and Game, Sacramento, California, 87 pp.

Jacobsen, G. S., J. E. Pearson, and T. M. Yuill. 1976. An epornitic of duck plague on a Wisconsin game farm. Journal of Wildlife Diseases 12: 20-25.

JANSEN, J. 1961. Duck plague. British Veterinary Journal 117: 349-356.

- 1968. Duck plague. Journal of the American Veterinary Medical Association 152: 1009-1016.

- AND H. KUNST. 1964. The reported incidence of duck plague in Europe and Asia. Tijdschrift Voor Diegeneeskunde 89: 765-769.

Jensen, W. I., AND C. S. Williams. 1964. Botulism and fowl cholera. In Waterfowl tomorrow, J. P. Linduska (ed.). U.S. Department of the Interior, Fisheries and Wildlife Service, Bureau of Sport Fisheries and Wildlife. U.S. Government Printing Office, Washington, D.C., pp. 333-341.

LEIBovitz, L. 1968. Progress report: Duck plague surveillance of American Anseriformes. Bulletin of the Wildlife Disease Association 4: 87-91.

. 1971. Duck plague. In Infectious and parasitic diseases of wild birds, J. W. Davis, R. C. Anderson, L. Karstad and D. O. Trainer (eds.). 
Iowa State University Press, Ames, Iowa, pp. 2233.

. 1991. Duck virus enteritis (duck plague). In Diseases of poultry, 9th ed., B. W. Calnek, H. J. Barnes, C. W. Beard, W. M. Reid and H. W. Yoder, Jr. (eds.). Iowa State University Press, Ames, Iowa, pp. 609-618.

— A.ND J. HWANG. 1968. Duck plague on the American continent. Avian Diseases 12: 361 $\neg 78$.

LIN, W., K. M. LAM, AND W. E. ClaRk. 1984. Isolation of an apathogenic immunogenic strain of duck enteritis virus from waterfowl in California. Avian Diseases 28: 641-6.50.

LOCKE, L., L. LeibovitZ, C. M. HERMAN, AND J. W. WALKER. 1968. Duck viral enteritis (duck plague) in North American waterfowl. In Proceedings of the 22nd Annual Conference, Southeastern Association of Game and Fish Commissioners, J. W. Webb (ed.), Columbia, South Carolina, pp. 96-98.

LUCAM, F. 1949. La peste aviare en France. In Report of the XIVth International Veterinary Congress, London, II. Published for the Ministry of Agriculture and Fisheries by His Majestys Stationery Office, London, England, pp, 380-382.

Montali, R. J., M. Bush, and G. A. Greeniwell. 1976. An epornitic of duck viral enteritis in a zoological park. Journal of the American Veterinary Medical Association 169: 954-958.

Mukerji, A., M. S. DAS, B. B. Ghosh, AND J. L. Gavciuly. 1963. Duck plague in West Bengal. I and II. Indian Veterinary Journal 40: 457-462.

$\longrightarrow, \longrightarrow$, AND - 1965. Duck plague in West bengal. III. Indian Veterinary Journal 42: 811-815.

NewCOMB, S. S. 1968. Duck viral enteritis (duck plague) epizootiology and related investigations. Journal of the American Veterinary Medical Association 153: 1897-1902.
Proctor, S. J., G. L. Pearson, and L. Leibovitz. 1975. Duck plague in free-flying waterfowl. Wildlife Disease Microfiche No. 59, Wildlife Disease Association, Lawrence, Kansas, 59 pp.

Rosen, M. N. 1972. The 1970-71 avian cholera epornitic's impacts on certain species. Journal of Wildlife Diseases 8: 75-78.

Sanderson, G. C., AND F. C. Bellrose. 1986. A review of the problem of lead poisoning in waterfowl. Illinois Natural History Survey, Special Publication 4, Champaign, Illinois, 34 pp.

SNYDER, S. B., J. H. FoX, L. H. CAMPBElL, K. F. TAM, AND (O. A. SOAVE. 1973. An epornitic of duck virus enteritis (duck plague) in California. Journal of the American Veterinary Medical Association 163: 647-652.

SPIEKER, J. O., T. M. YUILl, AND E. C. BURGesS. 1996. Virulence of six strains of duck plague virus in eight waterfowl species. Journal of Wildlife Diseases 32: 453-460.

Walker, J. W., C. J. Pfow, S. S. NewComb, W. D. UrbaN, H. E. Nadler, ANd L. N. Locke. 1969. Status of duck virus enteritis (duck plague) in the United States. In Proceedings of the 73rd Meeting, United States Animal Health Association, Richmond, Virginia, pp. 254-278.

WOBESER, G. 1987. Experimental duck plague in blue-winged teal and Canada geese. Joumal of Wildlife Diseases 23: 368-375.

—, AND D. E. DOChenTY. 1987. A solitary case of duck plague in a wild mallard. Journal of Wildlife Diseases 23: 479-482.

WOLF, K., AND C. N. BURKE. 1982. Survival of duck plague virus in water from Lake Andes National Wildlife Refuge, South Dakota. Journal of Wildlife Diseases 18: 437-440.

Received for publication 19 February 1996. 